\title{
THE ANALYSIS OF ECONOMIC POTENTIAL IN NORTH SUMATERA PROVINCE
}

\author{
Ahmad Habibi Harahap ${ }^{1 *}$, Eko Wahyu Nugrahadi² \\ 1*) Postgraduate Program, Universitas Negeri Medan \\ ${ }^{2}$ Faculty of Economics, Universitas Negeri medan \\ Email: ahmadhabibi@gmail.com
}

\begin{abstract}
Economic growth of North Sumatera Province is not quite on the top of optimum. If the compared by some of others province in Indonesia and by all of his potention, the North Sumatera Province only on the $10^{\text {th }}$ rank of economic growth in Indonesia in 2009-2013 period. The purpose of this study is toanalyze the economic sectors which are the basis in each district/city in North Sumatera province and to determine the structure of economic growth in the district /city both sectoral and aggregate the province of North Sumatera. Structural transformation to some extent will have an impact on overall economic growth. Analysis tools used in this study is Location Quetiont (LQ), Growth Ratio Model (MRP), overlay analysis, and shift share analysis. Results of this study showed that the agriculture sector is a sector which is the basis in nearly 13 districts/cities in North Sumatera Province. But the growth in agriculture, processing industries, mining and quarrying, and the electricity, gas \& water supply sector likely slowed, otherwise all tertiary sectors which include: trade, hotels, and restaurants; transportation and communication, finance, leasing, and services company, and the services sector is likely to experience growth positive. Transportation and communication is a sector with the highest growth occurring in North Sumatera Province. Shift Share Analysis results showed that in the Province of North Sumatera is going structural transformation characterized by decreasing the role of the agricultural sector, and the increasing role of the service sector. This condition as well as contrary to the Kuznets theory which states that the process of structural transformation contribution marked by shifting agriculture to manufacturing and then to services sector.
\end{abstract}

Key words: $L Q, M R P$, and structural transformation

\section{INTRODUCTION}

conomic problems are a matter of concern for all countries, especially in developing countries. This is quite reasonable because economic problems are closely related to efforts to improve people's welfare. "Economic development is a process that causes the per capita income of the population to increase in the long term which can promote the improvement of the economic welfare of the poor". (Sarwedi, 2010: 1). Economic development is inseparable from growth and change. In his empirical study, Chenery provides an explanation that development is a process of growth and change that can be observed where the characteristics are almost the same 
in every country (Roosmawarni, Soekarnoto, 2013: 37). According to Kuznets, economic growth is an increase in the capacity or capacity in the long run of a country in order to provide various needs for economic goods for the population of that country, an increase in capacity or capability itself will be possible or can be determined by progress and adjustments to the latest technology, institutional (institutional), as well as ideology against the various existing demands (Restiatun, 2009: 84).

North Sumatra Province is one of the provinces with a large population in Indonesia, with a population of more than 13,590,249 people in 2013. North Sumatra is also a province with a large area with a land area of $72,981.23 \mathrm{~km}^{2}$, and has potential abundant natural resources and human resources. These resources include the plantation industry, processing industry, manufacturing industry, and others. The economy of North Sumatera Province has experienced high growth every year. In comparison to the national growth, the economic growth of North Sumatera has not been left behind. It can be seen that the average growth is higher than the national growth, and there is an increase in economic growth in North Sumatra which is quite good as seen in the following figure:

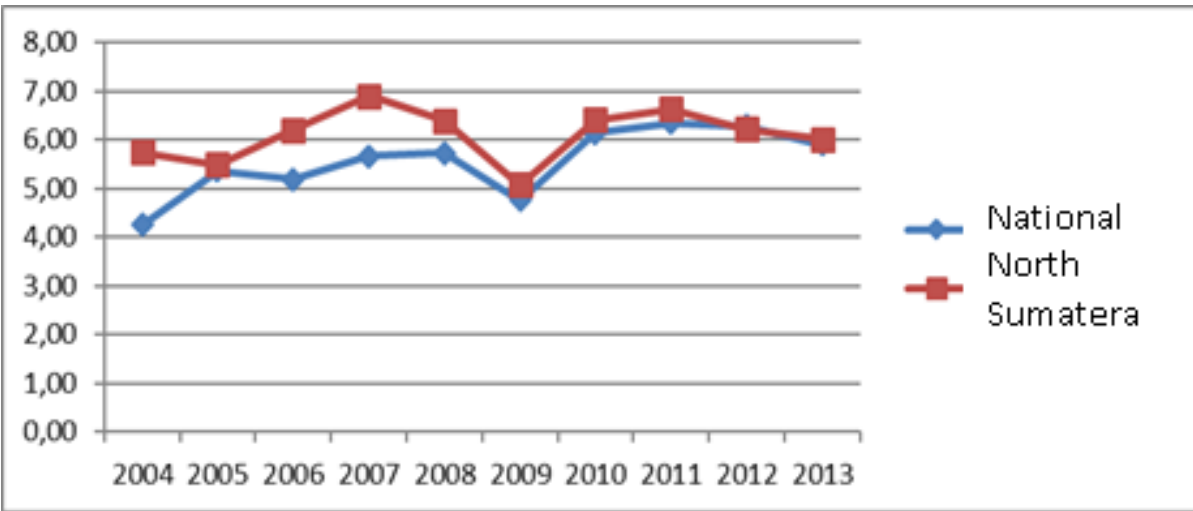

Figure 1: Economic Growth of Indonesia and North Sumatra Province in 2004 - 2013 (Percent)

Source: Statistics Indonesia, 2013 (processed)

From this figure, it can be seen that in the last ten years the average percentage of economic growth in North Sumatra Province is still relatively higher than the average national economic growth. North Sumatra's economic growth is supported by nine economic sectors whose growth in the last five years has been relatively different each year.

Such as the agricultural sector, which includes the food crops sub-sector, plantation crops, livestock and forestry and fishery products. Until 2002, agriculture was the mainstay of North Sumatra in the creation of GRDP, however from 2003-2013 the role of this sector was shifted by the manufacturing sector. In 2013, the contribution of the agricultural sector in the current price GRDP decreased from $21.89 \%$ to $21.32 \%$. This decrease was caused by a decrease in all sub-sectors except for the livestock sector and its products and the fisheries sub-sector. The mining and quarrying sector experienced an increase from 2012-2013 from the previous $2.04 \%$ to $5.48 \%$. This increase in growth 
was due to the growth in the oil and gas subsector, namely $2.65 \%$ in 2013 . After previously experiencing a contraction of minus $5.05 \%$ in 2012 . The manufacturing sector experienced a growth of $4.04 \%$ compared to the previous year which grew only $3.36 \%$. This is due to the accelerated growth in the non-oil and gas industry, while the oil and gas industry experienced a decline, petroleum refining experienced a contraction, from $6.98 \%$ in 2012 to $4.74 \%$ in 2013 . In contrast to the non-oil and gas industry sub-sector, which experienced an increase of $4.05 \%$ in 2013 compared to the previous year, it grew by $3.62 \%$.

The electricity, gas and clean water sector experienced a growth of 3.95\% in 2013 after previously growing in 2012 of $2.99 \%$. This growth was supported by increased growth in the electricity and clean water subsectors with growth of $5.95 \%$ and $5.68 \%$ respectively, while the gas sub-sector experienced a contraction of minus $20.23 \%$. The construction sector growth in the construction sector in 2013 was 7.17\% higher than in 2012 which was $6.78 \%$. This is directly proportional to the increase in the electricity and clean water subsectors because these two sectors are related. An increase in construction, especially buildings, will increase the demand for electricity and clean water.

Hotel and restaurant trade sector. Overall, the added value of the PHR sector grew by $7.78 \%$ in 2013 compared to the previous year of $7.23 \%$. This accelerated growth is mainly supported by increased growth in the wholesale and retail trade and restaurants subsectors. The transportation and communication sector has a role as a driver of economic activity. In the era of globalization, the role of this sector is very vital and is an indicator of the progress of a nation. In 2013 this sector experienced a growth of $8.23 \%$, but experienced a slowdown in growth in 2013 to only $7.60 \%$ this was due to the decline in growth in the two sub-sectors which experienced a growth slowdown from $8.15 \%$ in 2012 to only 7.57. \% in 2013.

Real estate financial sector and financial services. In 2013 this sector experienced a growth in 2013 only amounting to $8.31 \%$ which previously reached $11.20 \%$. This is due to a slowdown in growth in the financial sub-sector (banks), from $21.61 \%$ to $10.76 \%$. Services sector grew by $7.13 \%$ in 2013 , down from $7.54 \%$ in the previous year. This is due to the slowdown in growth in the general government sub-sector, from $7.44 \%$ in 2013 down to $6.93 \%$ in 2013.

North Sumatra's economic growth is actually quite good as evidenced by the fact that its growth is relatively not lower than that of the national economy. However, the economy of North Sumatra still needs to be optimized, given the huge potential of North Sumatra, but its economic performance is not in line with its potential. North Sumatra's economic growth has not yet become one of the highest in Indonesia. In the span of time between 2009-2013, North Sumatra's economic growth only ranks $10^{\text {th }}$ in Indonesia with a growth rate of $6.01 \%$ in 2013, under the provinces of West Papua, Central Sulawesi, Gorontalo, South Sulawesi, North Sulawesi, Southeast Sulawesi, West Sulawesi, Central Kalimantan and Jambi. The nine provinces have consistently increased their economic growth above the economic growth of North Sumatra in the last five years. This can be seen in the following image: 


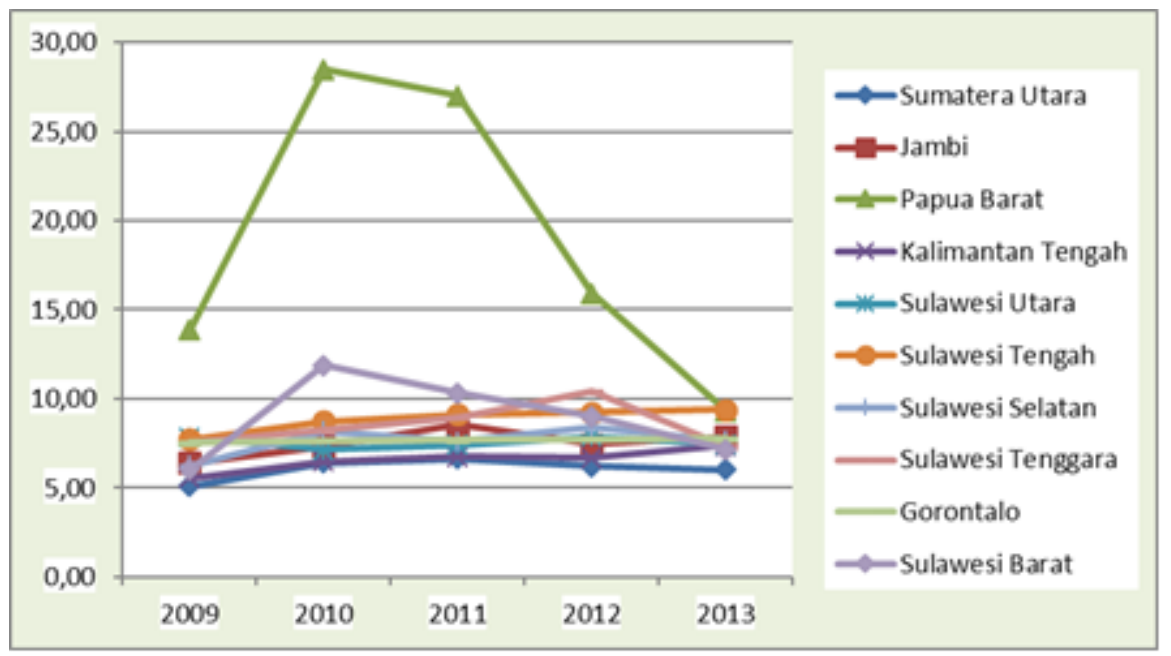

Figure 2: Economic Growth in North Sumatra and Several Provinces with Economic

Growth Above North Sumatra In Indonesia, 2009 - 2013 (Percent)

Source: Statistics Indonesia, 2013 (processed)

From the data above, it is clear that the economic growth of North Sumatera Province is not yet at its maximum, it requires a more in-depth analysis of the potential that can be optimized in North Sumatra Province. Geographical conditions, regional economic typologies that vary widely from region to region require different policy strategies, in order to be able to encourage accelerated development and economic growth in the regions, which are expected to provide a greater contribution to the regional economy of the Province. North Sumatra which will produce a true picture of the economic sectors with the most potential to serve as a priority scale in future economic development in North Sumatra Province.

From the description above, the authors want to analyze economic sectors in North Sumatra that can be developed and increased in terms of growth rates in supporting the economy of North Sumatra Province which will then be used as a priority scale in economic development in order to achieve more optimal economic growth in North Sumatra Province.

\section{RESEARCH METHOD}

This research is a descriptive analytical study, which provides a general description of the subject being examined in the form of data or numbers, which are then analyzed, classified, and interpreted in the form of descriptions, regarding the conditions of economic sectors in North Sumatra.

1. The economic sectors covered in this study are the nine economic sectors of North Sumatra and districts / cities in North Sumatra based on constant 2000 prices, namely A. Agriculture Sector, B. Mining and Excavation Sector, C. Manufacturing Industry Sector, D Electricity, Gas and Clean Water Sector, E. Building Sector, F. Trade, Hotel and Restaurant Sector, G. Transportation and Communication Sector, H. Finance, Leasing and Corporate Services Sector, I. Services Sector. 
2. The data series used in this study are the GRDP of North Sumatra Province and the GRDP of Regencies / Cities in North Sumatra at 2000 Constant Prices for the period 2004-2013.

The type of data used in this study is secondary data with a scale (time series) with a research period from 2004 - 2013 sourced from Statistics Indonesia is North Sumatra. The research location in this study is in the province of North Sumatra. And the research time was 2015. The reason the researchers chose North Sumatra as the location for their research was based on several things, namely; North Sumatra Province has geographic potential which has a land area consisting of mountains, lowlands, and coastal areas., And its rich sea area, a sea port that allows North Sumatra to conduct local to regional trade, North Sumatra also has abundant natural resources. both renewable (renewable resources) such as oil palm plantations, rubber, coffee and others. And natural resources that are not renewable (unrenewable resources), such as petroleum and others. North Sumatra also has a demographic potential with the fourth largest population in Indonesia and the first outside the island of Java.

The data collection technique in this research is through documentary studies, which is how to collect data through written documents, especially in the form of archives and also including certain books, opinions, theories or laws and others related to research problems.

\section{RESULT AND DISCUSSION}

\section{Macroeconomics Condition}

Economic growth is considered as an indicator of the success of a region's development. the greater the growth rate, the more successful the economic development will be. The economy can be said to be growing, it can be seen from the increase in output from the sectors that act as its constituents. North Sumatra economic data can be seen from the value of North Sumatra's GRDP at constant 2000 prices as shown in the figure below:

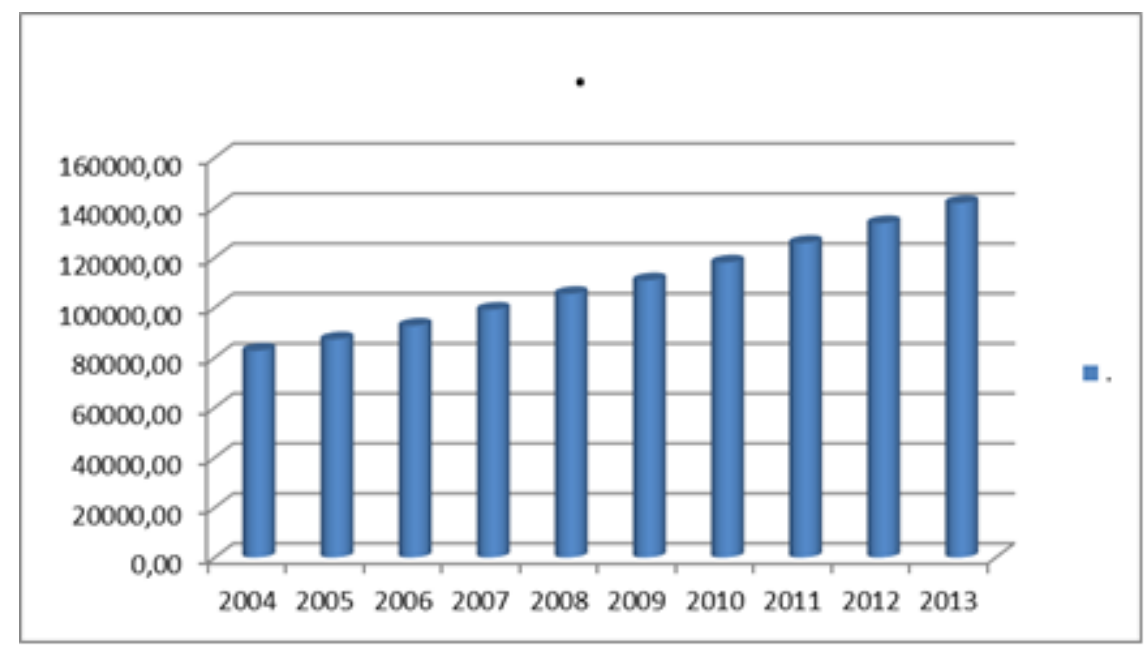

Figure 3: Development of Constant Price 2000 2003-2014 GRDP of North Sumatra Source: Central Bureau of Statistics, 2013 (processed) 
Quantitatively, North Sumatra's economic growth for ten years has experienced positive growth. This can be seen empirically by looking at the data in the graph above. Where the amount of GRDP in each year is greater than the value of GRDP of the previous year, this clearly indicates that for ten years in the research period the North Sumatra economy is in a positive trend.

The value of North Sumatra's GRDP in 2004 was IDR 82,675.24 billion, in 2005 it increased to IDR $87,240.28$ billion, in 2006 it increased to IDR $92,698.98$ billion and this increase continued in 2007 North Sumatra's GRDP of IDR 99,085, 67 billion, in 2008 amounting to IDR 105,431.88 billion, in 2009 IDR 110,850.71 billion, in 2010 IDR 117,979.00 billion, in 2011 IDR 125,805.40 billion, in 2012 IDR 133,702.86 billion and in 2013, which was valued at IDR 141768.86 billion.

The economic growth of North Sumatra during a period of 10 (ten) years, namely 20042013 can be seen in Figure 4.2. below where the economic growth of North Sumatra in 10 (ten) years, namely 2004-2013 as a whole experienced positive growth, in 2004 the economic growth in North Sumatra was (5.74\%), then in the following year 2005 the economy of North Sumatra experienced growth slightly lower than the previous year, namely 5.48\%, in 2006-2012 respectively (6.20\%), in 2007 (6.90\%), in 2008 (6.39\%), 2009 (5.07\%), 2010 (6.42\%), 2011 (6.63\%), and 2012 (6.22\%), and 2013 (6.01\%) . In general, the macro economy of North Sumatra can be said to be good when compared to the national level. This growth is supported by 9 (nine) economic sectors in the economic structure of North Sumatra.

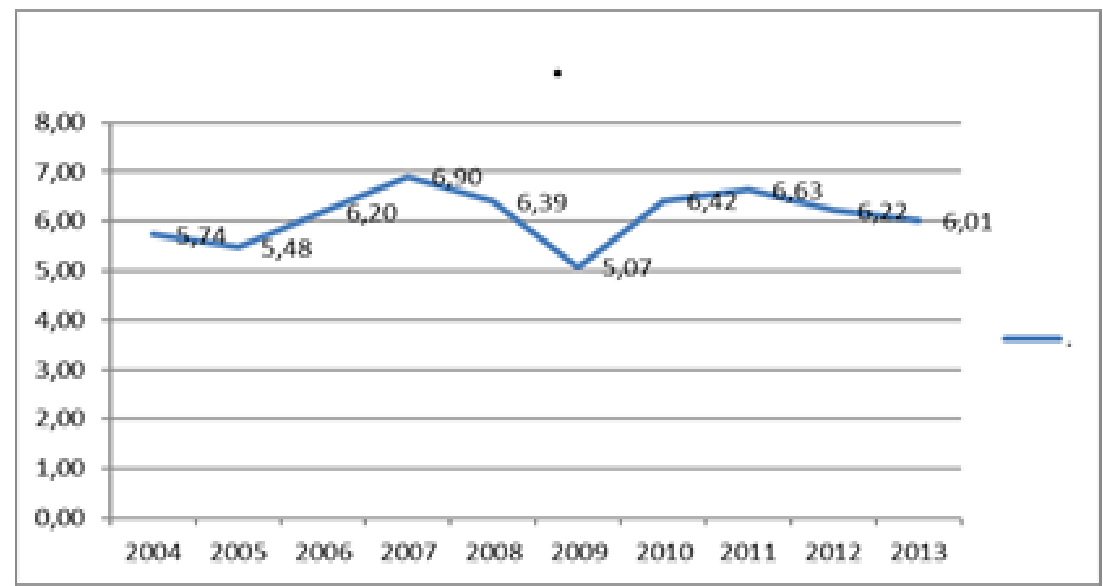

Source: Statistics Indonesia of North Sumatra, 2013 (processed)

However, North Sumatra's growth is still problematic where its growth is still stagnant at around $-+6 \%$ and is always volatile. This is due to, among other things: structural transformation (industrialization) is running slowly, productivity in the agricultural sector tends to be low, economic growth still needs to be boosted by investment, inadequate regional infrastructure to support efficient logistics. The quality of human resources is still low. The quality of local government spending does not support growth and the carrying capacity of the environment is reduced (Statistics Indonesia, 2014). From a number of these problems, the Government of North Sumatra should carry out various policies to increase the acceleration of economic growth in North Sumatra, 
including: Accelerating infrastructure development and developing the quality of human resources in order to optimize more dynamic growth in the future.

From a structural perspective, there has also been a shift in growth between sectors in the formation of GRDP as seen in the structure of the North Sumatra economy during the period 2004-2013, as seen in table 4.1. below this.

Table 1: The Economic Structure of North Sumatra 2004-2013

\begin{tabular}{|l|l|l|l|l|l|l|l|l|l|l|l|}
\hline No. & Business field & $\mathbf{2 0 0 4}$ & $\mathbf{2 0 0 5}$ & $\mathbf{2 0 0 6}$ & $\mathbf{2 0 0 7}$ & $\mathbf{2 0 0 8}$ & $\mathbf{2 0 0 9}$ & $\mathbf{2 0 1 0}$ & $\mathbf{2 0 1 1}$ & $\mathbf{2 0 1 2}$ & $\mathbf{2 0 1 3}$ \\
\hline 1. & Agriculture & 26 & 25 & 24 & 24 & 24 & 24 & 24 & 23 & 23 & 22 \\
\hline 2. & Mining \& Excavation & 1,2 & 1,2 & 1,2 & 1,2 & 1,2 & 1,2 & 1,2 & 1,2 & 1,1 & 1,1 \\
\hline 3. & Processing industry & 24 & 24 & 24 & 24 & 23 & 23 & 22 & 21 & 20 & 20 \\
\hline 4. & Electricity, Gas and Clean Water & 0,8 & 0,8 & 0,8 & 0,7 & 0,7 & 0,7 & 0,7 & 0,8 & 0,7 & 0,7 \\
\hline 5. & Building & 5,9 & 6,3 & 6,5 & 6,6 & 6,7 & 6,8 & 6,8 & 6,9 & 7 & 7 \\
\hline 6. & Trading, Hotel \& Rest & 18 & 18 & 18 & 18 & 18 & 19 & 18 & 19 & 19 & 19 \\
\hline 7. & Transportation \& Komniks & 8 & 8,4 & 8,9 & 9,1 & 9,3 & 9,6 & 9,8 & 10 & 10 & 10 \\
\hline 8. & K, P \& J & 6,1 & 6,2 & 6,4 & 6,7 & 7 & 6,8 & 7,4 & 7,9 & 8,3 & 8,4 \\
\hline 9. & Services & 9,5 & 9,4 & 9,5 & 9,6 & 9,9 & 9,5 & 10 & 10 & 10 & 10 \\
\hline & GRDP & 100 & 100 & 100 & 100 & 100 & 100 & 100 & 100 & 100 & 100 \\
\hline
\end{tabular}

Source: Statistics Indonesia of North Sumatra, 2013 (processed)

From the structure above, it can be seen that the agricultural sector still plays an important role in the formation of GDRP of North Sumatra. This can be seen from the portion of the agricultural sector that is still the largest in the GRDP structure for 10 (ten) years. However, this portion has continued to decline from $26 \%$ in 2004 to only $22 \%$ in 2013. Likewise, the manufacturing sector has the second largest share in the formation of GRDP after the agricultural sector also experienced the same thing as the agricultural sector. where the portion of the economic structure has decreased from $24 \%$ in 2004 to $20 \%$ in 2013.

\section{Location Quotient (LQ) Analysis}

Table 2: The Average LQ for Each Sector of North Sumatra, 2004-2013

\begin{tabular}{|c|c|c|c|c|c|c|c|c|c|c|}
\hline \multirow{2}{*}{ No. } & \multirow{2}{*}{ Regency / City } & \multicolumn{9}{|c|}{ The Average LQ for Each Sector } \\
\hline & & 1 & 2 & 3 & 4 & 5 & 6 & 7 & 8 & 9 \\
\hline 1. & Asahan & 1,04 & 0,15 & 1,91 & 1,23 & 0,33 & 1,1 & 0,31 & 0,3 & 0,34 \\
\hline 2. & Deli Serdang & 0,7 & 1,08 & 1,74 & 0,3 & 0,41 & 1,13 & 0,28 & 0,42 & 1,31 \\
\hline 3. & Hmb.Hasundutan & 2,36 & 0,18 & 0,01 & 0,47 & 0,58 & 0,9 & 0,46 & 0,44 & 1,48 \\
\hline 4. & Karo & 2,45 & 0,29 & 0,03 & 0,39 & 0,53 & 0,76 & 0,98 & 0,22 & 1,14 \\
\hline 5. & Labuhan Batu & 1,04 & 1,02 & 1,95 & 0,38 & 0,37 & 0,88 & 0,33 & 0,17 & 0,65 \\
\hline 6. & Langkat & 2,27 & 5,4 & 0,48 & 0,46 & 0,37 & 0,84 & 0,24 & 0,24 & 0,57 \\
\hline 7. & Madina & 1,93 & 1,41 & 0,16 & 0,28 & 1,65 & 0,93 & 0,4 & 0,28 & 1,42 \\
\hline 8. & Nias Selatan & 1,79 & 1,12 & 0,06 & 0,27 & 1,63 & 1,31 & 0,63 & 0,55 & 0,89 \\
\hline 9. & Pakpak Barat & 2,74 & 0,05 & 0,01 & 0,31 & 1,53 & 0,62 & 0,12 & 0,19 & 0,93 \\
\hline 10. & Samosir & 2,68 & 0,03 & 0,16 & 0,32 & 0,13 & 0,48 & 0,15 & 0,25 & 1,93 \\
\hline 11. & Sergai & 1,7 & 1,14 & 0,84 & 0,8 & 1,37 & 0,86 & 0,07 & 0,47 & 0,9 \\
\hline 12. & Simalungun & 2,42 & 0,3 & 0,68 & 0,64 & 0,26 & 0,44 & 0,27 & 0,28 & 1,15 \\
\hline 13. & Tapanuli Tengah & 1,96 & 0,61 & 0,52 & 0,82 & 0,7 & 0,61 & 0,24 & 0,5 & 1,83 \\
\hline
\end{tabular}




\begin{tabular}{|l|l|l|l|l|l|l|l|l|l|l|} 
14. & Kota Binjai & 0,31 & 5,34 & 0,97 & 1,92 & 1,32 & 0,89 & 0,49 & 2,31 & 1,68 \\
\hline 15. & Kota Medan & 0,09 & 0 & 0,61 & 1,91 & 1,66 & 1,44 & 2,09 & 2,03 & 1,06 \\
\hline 16. & Pdg. Sidempuan & 0,63 & 0,26 & 0,49 & 0,77 & 0,79 & 1,34 & 1,03 & 1,82 & 2,02 \\
\hline 17. & Pmtg. Siantar & 0,15 & 0,05 & 0,55 & 1,65 & 1,27 & 1,67 & 1,79 & 1,76 & 1,4 \\
\hline 18. & Sibolga & 1,03 & 0,01 & 0,36 & 0,87 & 0,78 & 1,12 & 1,37 & 1,28 & 1,86 \\
\hline 19. & Tanjung Balai & 0,94 & 2,1 & 0,84 & 0,75 & 1,19 & 1,16 & 0,84 & 0,71 & 1,29 \\
\hline 20. & Tebing Tinggi & 0,07 & 0,1 & 0,65 & 0,56 & 1,26 & 1,36 & 1,86 & 1,33 & 2,3 \\
\hline
\end{tabular}

Source: processed data

From the data calculated from the Location Quotient (LQ) above, it can be explained that there are 4 (four) sectors which are the leading sectors or basic sectors in Asahan Regency, namely the agricultural sector, the manufacturing industry sector, the electricity, gas \& clean water sector, as well as the trade, hotel sector. \& restaurants. and 5 (five) other sectors are not basic sectors. The sector that is the most dominant in Asahan is the manufacturing sector, where the average contribution to Asahan's GRDP is $42.8 \%$, much greater than the contribution of the same sector at the provincial level of North Sumatra which is only around $22.5 \%$ in the GRDP structure of North Sumatra. . Meanwhile, the most lagging sector is the financial, leasing \& corporate services sector which only contributed $2.09 \%$, this is much lower than the same sector at the North Sumatra Province level which was 7.12\%. Deli Serdang Regency has 4 (four) leading sectors or base sectors, namely the mining \& quarrying sector, the manufacturing industry sector, the hotel \& restaurant trade sector, and the services sector, and 5 (five) other sectors are non-superior sectors in Deli Serdang. The most prominent sector in Deli Serdang is the manufacturing sector which contributes an average of $39.2 \%$, this is higher than the same sector at the North Sumatra Province level of $22.5 \%$. The most underdeveloped sector is the transportation and communication sector which only contributes to the GDP of Deli Serdang by an average of $2.75 \%$, this is much lower than the contribution of the same sector at the North Sumatra level which is an average of $9.4 \%$.

From the description above, it can be concluded that there are 4 (four) sectors that mostly form the basis sectors in various districts / cities in North Sumatra, the service sector, the agricultural sector, the building sector, and the trade, hotel \& restaurant sector. This is in accordance with research conducted by Anita Roosmawarni and Soekarnoto with the research title Analysis of economic growth and structural transformation in East Java province for the period 2000-2010.

\section{Growth Ratio Model Analysis (MRP)}

Table 3: GRM Value Each Sector

\begin{tabular}{|l|c|c|c|c|c|c|c|c|c|c|}
\hline & \multicolumn{10}{c|}{ GRM Value Each Sector } \\
\cline { 2 - 14 } & $\mathbf{1}$ & $\mathbf{2}$ & $\mathbf{3}$ & $\mathbf{4}$ & $\mathbf{5}$ & $\mathbf{6}$ & $\mathbf{7}$ & $\mathbf{8}$ \\
\hline \multirow{2}{*}{$\begin{array}{l}\text { Average } \\
\text { Notation }\end{array}$} & 0,98 & 0,98 & 0,98 & 0,98 & 1,02 & 1,01 & 1,03 & 1,03 & 1,01 \\
\cline { 2 - 12 } & - & - & - & - & + & + & + & + & + \\
\hline
\end{tabular}




\begin{tabular}{|c|c|c|c|c|c|c|c|c|c|c|}
\hline \multirow{2}{*}{ No. } & \multirow{2}{*}{ Regency / City } & \multicolumn{9}{|c|}{ GRS Value Per Sector } \\
\hline & & 1 & 2 & 3 & 4 & 5 & 6 & 7 & 8 & 9 \\
\hline 1. & Asahan & 0,99 & 1 & 1,02 & 1,01 & 0,97 & 0,98 & 0,96 & 0,95 & 0,98 \\
\hline 2. & Deli Serdang & 1 & 1,04 & 1,01 & 1,02 & 1 & 0,99 & 1,32 & 1,01 & 1,01 \\
\hline 3. & Hmb.Hasundutan & 0,99 & 1,04 & 1,03 & 1,04 & 0,99 & 1,02 & 0,99 & 0,97 & 1,01 \\
\hline 4. & Karo & 1 & 1,04 & 1 & 1 & 0,97 & 1,01 & 0,95 & 0,96 & 1,01 \\
\hline 5. & Labuhan Batu & 1,01 & 1,04 & 1,02 & 1,02 & 0,98 & 1 & 0,97 & 0,98 & 0,99 \\
\hline 6. & Langkat & 1 & 0,93 & 1,01 & 1,01 & 0,99 & 1 & 0,95 & 1,01 & 0,98 \\
\hline 7. & Madina & 1 & 1,01 & 1,02 & 1,04 & 1,03 & 0,99 & 0,99 & 0,98 & 1,03 \\
\hline 8. & Nias Selatan & 0,98 & 1,03 & 1,03 & 1,02 & 0,99 & 0,97 & 0,96 & 0,98 & 1 \\
\hline 9. & Pakpak Barat & 1 & 1,01 & 0,98 & 1,03 & 1,03 & 1 & 1 & 1,01 & 1,03 \\
\hline 10. & Samosir & 1,05 & 0,97 & 0,9 & 0,94 & 0,91 & 0,97 & 0,91 & 1,03 & 0,97 \\
\hline 11. & Sergai & 1 & 1,04 & 1,01 & 1,05 & 1,03 & 0,99 & 0,98 & 0,98 & 1,02 \\
\hline 12. & Simalungun & 1 & 1,03 & 0,99 & 1,03 & 0,97 & 0,98 & 0,97 & 0,99 & 1,02 \\
\hline 13. & Tapanuli Tengah & 1 & 1,02 & 1 & 1,05 & 1,04 & 1,02 & 1 & 0,99 & 1,02 \\
\hline 14. & Kota Binjai & 0,99 & 1,12 & 1 & 1,03 & 1,01 & 0,98 & 1 & 0,96 & 1 \\
\hline 15. & Kota Medan & 0,98 & 0 & 1 & 0,99 & 1 & 1,01 & 0,98 & 0,98 & 1 \\
\hline 16. & Pdg. Sidempuan & 1 & 0,99 & 1 & 0,99 & 1 & 0,98 & 0,96 & 1 & 0,99 \\
\hline 17. & Pmtg. Siantar & 0,96 & 0,93 & 0,98 & 1 & 0,96 & 1,01 & 0,95 & 0,98 & 0,96 \\
\hline 18. & Sibolga & 1 & 1,02 & 1,01 & 0,99 & 0,97 & 0,98 & 1 & 0,97 & 0,98 \\
\hline 19. & Tanjung Balai & 0,98 & 1,1 & 0,98 & 1,01 & 0,99 & 0,99 & 0,97 & 1 & 0,98 \\
\hline 20. & Tebing Tinggi & 0,97 & 1,01 & 1 & 1,01 & 0,99 & 1 & 0,97 & 0,99 & 0,98 \\
\hline
\end{tabular}

Source: processed data

From the calculation of the Growth Ratio Model in terms of Reference Growth Ratio (RGR), it can be explained that there are 5 (five) sectors that have a value of GRR> 1, which means that the sector has a higher growth value than the GRDP growth value at the reference level (at the the same), namely the building sector, the hotel \& restaurant trade sector, the transportation \& communication sector, the financial sector, leasing \& corporate services, and the services sector. From the results of the calculation of the Growth Ratio Model (GRM) above, it can be explained that in Asahan Regency there are 4 (four) sectors that have GRR> RPR, namely the agricultural sector, the mining \& excavation sector, the manufacturing industry sector, and the electricity, gas \& clean water sector. Deli Serdang Regency has 5 (five) sectors that have GRS> GRM, namely the agriculture sector, mining \& quarrying sector, processing industry sector, electricity, gas \& clean water sector, and transportation \& communication sector.

From the results of the analysis above, it can also be explained that the sectoral growth pattern in North Sumatra tends to be dominated by service sectors, and there are 5 (five) sectors that are mostly found in various districts / cities which have a GRS value>1, which means that these sectors are The study area has higher growth compared to the same sectors at the reference area level (North Sumatra Province), namely the 
electricity, gas \& water supply sector, the manufacturing sector, the mining \& mining sector, the agriculture sector and the services sector.

\section{Klassen Typology Analysis}

Table 4: Typology Classification of Sectoral Approaches

\begin{tabular}{|c|c|c|c|c|c|c|c|c|c|c|}
\hline \multirow{2}{*}{ NO } & \multirow{2}{*}{ Regency / City } & \multicolumn{9}{|c|}{ Regional Sectoral Typology of Regencies / Cities in North Sumatra } \\
\hline & & 1 & 2 & 3 & 4 & 5 & 6 & 7 & 8 & 9 \\
\hline 1. & ASAHAN & CMCT & BC & СMCT & СMCT & RT & CMTT & RT & RT & RT \\
\hline 2. & DELI SERDANG & $\mathrm{BC}$ & CMCT & СMCT & $\mathrm{BC}$ & $\mathrm{BC}$ & CMTT & $\mathrm{BC}$ & RT & CMCT \\
\hline 3. & HUMBAN. HASUNDUTAN. & CMCT & BC & $\mathrm{BC}$ & $\mathrm{BC}$ & RT & $B C$ & RT & RT & СMCT \\
\hline 4. & KARO & СMCT & BC & $B C$ & $\mathrm{BC}$ & RT & $\mathrm{BC}$ & RT & RT & CMTT \\
\hline 5. & LABUHANBATU RAYA & СMCT & CMCT & СMCT & $\mathrm{BC}$ & RT & RT & RT & RT & RT \\
\hline 6. & LANGKAT & СMCT & CMTT & $\mathrm{BC}$ & $\mathrm{BC}$ & RT & RT & RT & RT & RT \\
\hline 7. & MANDAILING NATAL & СMCT & CMCT & $B C$ & BC & СMCT & RT & RT & RT & СMCT \\
\hline 8. & NIAS SELATAN & СMTT & CMCT & $\mathrm{BC}$ & $B C$ & CMTT & CMTT & RT & RT & RT \\
\hline 9. & PAKPAK BARAT & СMCT & BC & $\mathrm{BC}$ & $\mathrm{BC}$ & СMCT & RT & RT & RT & BC \\
\hline 10. & SAMOSIR & СMCT & RT & RT & RT & RT & RT & RT & $B C$ & CMTT \\
\hline 11. & SERDANG BEDAGAI & СMCT & CMCT & $\mathrm{BC}$ & $\mathrm{BC}$ & CMCT & RT & RT & RT & BC \\
\hline 12. & SIMALUNGUN & СMCT & $B C$ & $\mathrm{BC}$ & $\mathrm{BC}$ & RT & RT & RT & RT & СMCT \\
\hline 13. & TAPANULI TENGAH & СMCT & BC & $\mathrm{BC}$ & $\mathrm{BC}$ & $\mathrm{BC}$ & BC & RT & RT & СMCT \\
\hline 14. & BINJAI & $\mathrm{BC}$ & CMCT & СMCT & СMCT & CMTT & RT & RT & CMTT & CMTT \\
\hline 15. & MEDAN & $\mathrm{BC}$ & RT & $\mathrm{BC}$ & CMCT & CMTT & $\mathrm{CMCT}$ & CMTT & CMTT & CMTT \\
\hline 16. & PADANG SIDEMPUAN & $\mathrm{BC}$ & BC & $\mathrm{BC}$ & $\mathrm{BC}$ & RT & CMTT & CMTT & CMTT & CMTT \\
\hline 17. & PEMATANG SIANTAR & RT & RT & $\mathrm{BC}$ & СMCT & CMTT & СMCT & CMTT & CMTT & CMTT \\
\hline 18. & SIBOLGA & СMCT & $\mathrm{BC}$ & $\mathrm{BC}$ & $\mathrm{BC}$ & RT & CMTT & CMTT & CMTT & CMTT \\
\hline 19. & TANJUNG BALAI & RT & CMCT & RT & $\mathrm{BC}$ & СMTT & CMTT & BC & RT & CMTT \\
\hline 20. & TEBING TINGGI & RT & $B C$ & $B C$ & $B C$ & CMTT & CMTT & CMTT & CMTT & CMTT \\
\hline
\end{tabular}

Source: processed data

From the table data above, it can be explained that Asahan Regency has 3 (three) sectors with a CMCT typology, namely the agricultural sector, the manufacturing industry sector, and the electricity, gas \& clean water sector, 1 (one) CMTT typology sector, namely the trade, hotel \& restaurant sector, 1 (one) BC sector, namely the mining \& excavation sector, and 4 (four) RT with a RT typology, namely the building sector, the transportation \& communication sector, the financial sector, leasing \& corporate services, and the services sector. Deli Serdang Regency has 3 (three) CMCT typology sectors, namely the mining \& excavation sector, the processing industry sector, and the services sector, 1 (one) CMTT typology sector namely the trade, hotel \& restaurant sector, 4 (four) BC typology sectors, namely agriculture sector, electricity, gas \& clean water sector, building sector, and transportation \& communication sector, and 1 (one) household sector with the typology, namely the financial sector, leasing \& corporate services. 
And the 3 (three) most underdeveloped sectors with RT typology that are mostly found are the financial sector, leasing \& corporate services, and the transportation \& communication sector, each of which is spread across 13 (thirteen) districts / cities as well as the trade, hotel \& business sector. restaurants spread over 8 (eight) districts / cities.

\section{Shift-Share Analysis (Industrial Mix)}

Table 5: Industrial Mix Values

\begin{tabular}{|c|c|c|c|c|c|c|c|c|c|}
\hline \multirow{2}{*}{ Year } & \multicolumn{9}{|c|}{ Industrial Mix Values } \\
\hline & 1 & 2 & 3 & 4 & 5 & 6 & 7 & 8 & 9 \\
\hline 2004 & $-0,0198$ & $-0,1628$ & $-0,0036$ & $-0,0253$ & 0,01825 & 0,00396 & 0,07753 & 0,01042 & 0,00435 \\
\hline 2005 & $-0,021$ & $-0,0086$ & $-0,0075$ & $-0,013$ & 0,07549 & $-0,0053$ & 0,04712 & 0,01721 & $-0,0112$ \\
\hline 2006 & $-0,0381$ & $-0,0172$ & $-0,0072$ & $-0,026$ & 0,04081 & 0,00722 & 0,05712 & 0,03625 & 0,00922 \\
\hline 2007 & $-0,0189$ & $-0,0267$ & $-0,0182$ & $-0,0677$ & 0,0082 & 0,00642 & 0,0302 & 0,05512 & 0,01349 \\
\hline 2008 & $-0,0037$ & $-0,0001$ & $-0,0347$ & $-0,0145$ & 0,01771 & $-0,0024$ & 0,02444 & 0,0489 & 0,03083 \\
\hline 2009 & 0,00862 & $-0,0255$ & $-0,0124$ & $-0,0141$ & 0,0248 & 0,0146 & 0,03563 & 0,0385 & $-0,04$ \\
\hline 2010 & $-0,0236$ & $-0,0178$ & $-0,0294$ & $-0,0001$ & $-0,0062$ & $-0,0097$ & 0,0202 & 0,09997 & 0,06326 \\
\hline 2011 & $-0,0128$ & $-0,0001$ & $-0,0501$ & $-0,0143$ & 0,01872 & 0,01433 & 0,03252 & 0,069 & 0,01681 \\
\hline 2012 & $-0,0149$ & $-0,0448$ & $-0,0256$ & $-0,0423$ & 0,00482 & 0,01043 & 0,02123 & 0,05003 & 0,01265 \\
\hline 2013 & $-0,02$ & $-0,0001$ & $-0,0197$ & $-0,0148$ & 0,0121 & 0,01728 & 0,01533 & 0,02299 & 0,01114 \\
\hline Average & $-0,0164$ & $-0,0304$ & $-0,0208$ & $-0,0232$ & 0,02147 & 0,00568 & 0,03613 & 0,04484 & 0,01106 \\
\hline
\end{tabular}

Source: processed data

From the results of the calculation of the growth value of the Industrial Mix, it can be explained that the growth value of the Agriculture sector for the last 10 (ten) years has decreased compared to the total GRDP growth value, with each growth value being negative except in 2009 which was $0.00862(0,86 \%)$, and the cumulative average growth in the agricultural sector is $-0.0164(-1.64 \%)$. The growth of the mining \& quarrying sector for the last 10 (ten) years has also decreased every year with a negative growth value compared to the total GDP growth with the cumulative average value of the mining \& excavation sector of -0.0304 (-3.04\%). The manufacturing sector during the study period also experienced a decline in growth compared to the total GDP growth with an average value of cumulative growth of $-0.0208(-2.08 \%)$. The electricity, gas \& clean water sector during the study period also experienced negative growth compared to the total GRDP growth value with a cumulative average growth value of -0.0232 ($2.32 \%)$.

From the results of the Industrial Mix Analysis, it can be concluded that there are 3 (three) sectors which cumulatively during the study period have the highest growth rate values. Each year, these sectors have a higher growth rate than the total GRDP growth, in other words that proportionally these sectors each year experience an increase in the GRDP structure of North Sumatra. These sectors are the financial sector, leasing \& corporate services, the transportation \& communication sector, and the building sector. The results of this study are broadly in accordance with the results of previous 
determinations carried out by Roosmawarni and Soekarnoto in the East Java region with the research title of economic growth analysis and structural transformation.

From the results of this analysis it is also in accordance with the theory put forward by Kuznets with the theory of structural change where in developing countries there will be a structural transformation process in which the role of the primary sector (agriculture \& mining) will gradually diminish in the formation of a country's GDP / GRDP. regions, on the other hand, the role of the services sector will increasingly increase in the formation of GDP / GRDP (Roosmaini, Sukarnoto, 2013: 37).

\section{CONCLUSIONS AND RECOMMENDATIONS}

\section{Conclusion}

In this chapter, we will convey a number of things regarding the results of data analysis which have been described in the previous chapter. From the conclusions there will be presented suggestions related to problems related to this research. So that it is expected that it will be able to be input in making decisions for the parties concerned. After conducting a series of studies and producing the results of analysis and discussion, the following conclusions can be drawn:

1. Based on the results of LQ calculations in 9 (nine) economic sectors in North Sumatra, it shows that the sectors that form the basis of most districts / cities in North Sumatra are the industrial sector, the agricultural sector, the building sector, and the trade, hotel \& restaurant sector.

2. From the results of the MRP calculation, it can be concluded that there are 5 (five) economic sectors that are dominant in economic growth in North Sumatra with the largest to smallest structures, namely the transportation \& communication sector, the financial sector, leasing \& company services, the building sector, trade, hotel \& restaurant sector, services sector, electricity, gas \& water supply sector, manufacturing sector, mining \& quarrying sector, agriculture sector.

3. Based on the results of the classification typology analysis, it can be concluded that there are 3 (three) most potential sectors scattered in various districts / cities in North Sumatra, namely the agricultural sector, the mining \& quarrying sector and the services sector.

4. Based on the results of IM calculations, it can be concluded that the economic structure of North Sumatra has undergone a structural transformation from the primary and industrial sectors to the services sector.

\section{Suggestion}

Based on the results of the research in the previous chapter, some suggestions are described to the North Sumatra government and its stakeholders regarding the overall economic development policy in North Sumatra, namely: 
1. Doing development by taking a priority scale against the basic sectors, namely the agricultural sector, and sectors that have high growth prospects, namely the services sector in North Sumatra.

2. Taking a policy of accelerating development towards sectors that support the economy of North Sumatra which is experiencing slowing growth, such as the agricultural sector, the industrial sector, and the electricity, gas \& clean water sector.

3. Readers who are interested in this research are advised to pay attention to the analysis of DLQ and local Klassen typology.

\section{REFERENCES}

Abipraja, S. (1993). Ekonomi Pembangunan Pengantar dan Kebijaksanaan. Airlangga University Press.

Adisasmita, R. (2005). Pembangunan Pedesaan dan Perkotaan. Yogyakarta: Graha Ilmu.

Adisasmita, R. (2008). Pengembangan Wilayah : Konsep dan Teori. yogyakarta: Graha IImu.

Arsyad, L. (1999). Ekonomi Pembangunan. Edisi Keempat. STIE YKPN.

arsyad, L. (1999). Pengantar Perencanaan dan Pembangunan Ekonomi Daerah. Yogyakarta: BPFE.

Badan Pusat Statistik Sumatera Utara. (2015). Sumatera Utara Dalam Angka. MEDAN: Badan Pusat Statistik Sumatera Utara.

Boediono. (1999). Teori Pertumbuhan Ekonomi. Yogyakarta: BPFE.

Budiharsono, S. (1996). Transformasi struktural dan Pertumbuhan Antar Daerah Di Indonesia 1969-1987.Disertasi tidak diterbitkan. Bogor: Program Pascasarjana Institut Pertanian Bogor BOGOR.

Daryanto, A. (2001). Social Accounting Matrix Model For Development Policy Analysis. Working Paper No. 3. Departement Of Agricultural Socio Economics, Bogor Agricultural University, Boggor

Dasril, A. S. (1993). Pertumbuhan dan Perubahan Struktur Produksi Sektor Pertanian dalam Industrialisasi Di Indonesia 1971-1990.Disertasi tidak diterbitkan Bogor: Program Pascasarjana Institut Pertanian Bogor BOGOR.

Djojohadikusumo, S. (1994). Perkembangan Pemikiran Ekonomi : Dasar Teori Ekonomi Pertumbuhan dan Ekonomi Pembangunan. jakarta: PT.Pustaka LP3ES Indonesia.

Erika, R., \& W, S. U. (2013). Analisis Sektor-Sektor Ekonomi Dalam Rangka Pengembangan KebijakanPembangunan Ekonomi Kota Kediri. JESP Vol.5 No. 1 , 63-78.

Glasson, J. (1997). Pengantar Perencanaan Regional. Jakarta: Fakultas Ekonomi Universitas Indonesia. 
Jhingan, M. (2003). Ekonomika Pembangunan Dan Perencanaan. Jakarta: P.T. Raja Grafindo Persada.

Kuncoro, M. (2000). Ekonomi Pembangunan: Teori, Masalah, dan Kebijakan. Yogyakarta: UPP AMPYKPN.

Kuncoro, M. (1997). Ekonomi Pembangunan, Teori, Masalah, dan Kebijakan, Akademi Peremajaan Perusahan. Yogyakarta: YKPN.

Ma'ruf, A. (2009). Anatomi Makro Ekonomi Regional : Studi Kasus Provinsi DIY. JEJAK, Vol. 2, No. 2 , 114-125.

Mondal, I. Wali (2009). An Analysis Of The Industrial Development Potential Of Malaysia : A Shift-Share Approach. Journal Of Business \& Ekonomics Research, Volume 7 Number 5, 41-46.

Prishardoyo, B. (2008). Analisis Tingkat Pertumbuhan Ekonomi dan Potensi Ekonomi Terhadap Produk Domestic Regional Brutto ( PDRB ) Kabupaten PATI Tahun 2000-2005. JEJAK, Volume 1, No. 1. , 1-9.

Ratnasari, E. D. (2014). Sectors Analysis And Determination Of GDP Forming Leading Sector In Distric KEBUMEN. Jurnal Fokus Bisnis, Volume 13, No. 1 , 1-29.

Restiatun. (2009). Identifikasi Sektor Unggulan dan Ketimpangan Antar Kabupaten / Kota Di Provinsi Daerah Istimewa Yogyakarta. Jurnal Ekonomi Dan Studi Pembangunan Vol. 10, No. 1 , 77-98.

Rosmawarni, A., \& Soekarnoto. (2013). AnalisisPertumbuhan Ekonomi Dan Transformasi Struktural Di Provinsi Jawa Timur. Jurnal Ekonomi Dan Bisnis Tahun XXIII No. 3 , 35-47.

Sarwedi. (2010). Analisis Determinan Perubahan Penawaran Barang Ekspor Indonesia. Buletin Ekonomi Moneter Dan Perbankan Vol. 12 No. 3. Jakarta: Bank Indonesia.

Sirojuzilam. (2008). Disparitas Ekonomi Dan Perencanaan Regional,Ketimpangan Ekonomi Wilayah Barat dan Wilayah Timur Provinsi Sumatera Utara. Pustaka Bangsa Press.

Sjafrizal. (2008). Ekonomi Regional, Teori dan Aflikasi, Cetakan Pertama. Padang: Baduose Media.

Soepomo, P. (1993). Analisis Shift Share "Perkembangan dan Penerapan". Jurnal Ekonomi dan Bisnis Indonesia .

Sufri, M. (2003). Analisis Daya saing Komuditas Ekspor Non Migas Dan Perubahan Struktur Ekonomi Implikasinya Terhadap kebijakan Pembangunan Di Sulawesi Selatan. Disertasi tidak diterbitkan.Surabaya: Program Pasca Sarjana Universitas Airlangga SURABAYA. 
Syrquin, M. (1988). Patterns of Structural Change, dalam (Chenery, H. and T.N. Srinivasan,eds.). Handbook of Development Economics. Elsevier Science Publishers.

Tarigan, R. (2007). Ekonomi Regional Teori dan Aplikasi Edisi Revisi. Jakarta: Bumi Aksara.

Todaro, M. P. (2000). Pembangunan Ekonomi di Dunia Ketiga (Terjemahan)

Edisi Ketujuh. Jakarta: Erlangga.

Todaro, Michael, P., \& Stephen, S. (2004). Pembangunan Ekonomi, Edisi kesembilan. Jakarta: Erlangga.

Yusuf, M. (2012). Ilmu Ekonomi Regional. Medan: Perdana Mulya Sarana.

Yusuf, M. (1999). Model Rasio Pertumbuhan (MRP) Sebagai salah satu Alat Analisis Alternatif dalam Perencanaan Wilayah dan Kota Aflikasi Model: Wilayah Bangka Belitung. EKI Vol.XLVII No. 2 , 219-233. 